\title{
Assessment of Reproductive Traits of Different Androgenic Pepper Lines (Capsicum annuum L.)
}

\author{
Fidanka Trajkova $^{1^{*}}$ and Liljana Koleva Gudeva ${ }^{1}$ \\ ${ }^{1}$ Department of Plant Biotechnology, Faculty of Agriculture, Goce Delcev University - Stip, \\ Krste Misirkov, 10-A, 2000 Stip, Republic of Macedonia.
}

\begin{abstract}
Authors' contributions
This work was carried out in collaboration between listed authors. Author FT carried the experimental work, performed the statistical analysis, literature collection and manuscript writing. Author LKG was in charge of overall planning and supervision of the experiment and participated in manuscript preparation. Both authors read and approved the final manuscript.
\end{abstract}

Article Information

DOI: $10.9734 / A R R B / 2017 / 37324$

Editor(s):

(1) George Perry, Dean and Professor of Biology, University of Texas at San Antonio, USA.

Reviewers:

(1) İran Ersin Akinci, Turkey.

(2) Nikolay Panayotov, Agrarian University - Plovdiv, Bulgaria. Complete Peer review History: http://www.sciencedomain.org/review-history/21732

Original Research Article

Received $11^{\text {th }}$ October 2017

Accepted $30^{\text {th }}$ October 2017

Published $3^{\text {rd }}$ November 2017

\begin{abstract}
The biology of pepper growth and development is strongly dependent on complex influence of environmental abiotic factors as light, temperature, air humidity and soil moisture. The presence and length of different pepper phenophases are variety characteristics, which they expressed as result of the development in specific agroecological conditions. In this study the vegetation period as earliness indicator of seven androgenic pepper lines derived from 3 different sweet pepper varieties was studied during four years experiment under greenhouse conditions. The studied androgenic pepper lines KK1 and KK2 were derived via androgenesis from the sweet pepper variety Kurtovska kapia (KKk), P3 and P4 from the variety Piran (Pk) and F5, F6 and F7 derived from the variety Feherozon (Fk). The length of the vegetation period of the seven androgenic lines was compared to the vegetation period of their parental genotypes, respectively. Based on estimated length of vegetation period the androgenic lines were grouped in two groups as early ripening pepper androgenic lines and late ripening pepper androgenic lines. Alongside, there is a significant and positive association of days to flowering and days to fruiting with days to horticultural and physiological fruit maturity.
\end{abstract}


These androgenic genotypes are valuable breeding resources for improvement of earliness of sweet pepper genotypes in order to fulfill the needs of pepper producers and consumers.

Keywords: Pepper; androgenic lines; germination; flowering; vegetation period; earliness; correlation.

\section{INTRODUCTION}

Pepper (Capsicum annuum L.) is one of the most important Solanaceae species cultivated worldwide. The biology of pepper growth and development is strongly dependent on genetic inheritance and complex influence of environmental abiotic factor, as well as cultivation practices [1-3]. In certain agri-climatic conditions, optimal sowing or planting time ensures proper growth and development of pepper crop resulting maximum yield and economic utilization of agricultural land [4]. The fruit yield of any crop, including peppers, is largely influenced by its earliness and duration of its reproductive period [5]. As thermophile crop, pepper optimum temperature for the best phenological expression is $20-25^{\circ} \mathrm{C}$, while flowering and fruit ripening have the best performance during 12-hours daylight $[6,7]$. On the other hand, minimum temperature for seed germination is $22-25^{\circ} \mathrm{C}$, when the germination starts after 6-7 days. If there is a light shortage, the plants are elongated, flowers and fruits aborted and vegetative organs enlarged [6]. Abiotic factors have great effect on bell pepper capsaicin content, yield and yield contributing characteristics [8].

The duration of different phenophases in pepper development is distinctive for different pepper varieties. According to different authors vegetation period of pepper is defined differently. It is defined as the period from plant emergence to appearance of first fruits in physiologically mature stage [7]. Also, the length of pepper phenological phases is estimated starting either from sowing or transplanting date [9]. However, the terms earliness to horticulturally (technological) and physiologically (botanical) mature stages are used in commercial production and the harvest in certain mature stage depends on the characteristics and utilization of pepper fruit $[7,10]$. This definition is the most suitable for Balkans because of the cultivated pepper varieties and their consumption in different fruit phenophases.

Yet, there is limited knowledge regarding reproductive traits of androgenic genotypes derived from commercial varieties of peppers and characterization of their reproductive traits in real agrometeorological conditions [10]. Different morphological and molecular characters of androgenic lines are researched [11-15], but evaluation of their reproductive traits and the correlation of reproductive and economically important traits is very limited at present.

The objective of this study was to assess reproductive traits and their correlation for seven androgenic pepper lines derived from 3 different sweet pepper varieties, with an emphasis on earliness as economically important trait.

\section{MATERIALS AND METHODS}

The method of androgenesis was successfully applied for development of fertile androgenic plants in vitro conditions from the three varieties Kurtovska kapia, Piran and Feherozon. Antherdonor plants were grown under greenhouse conditions. The flower buds were harvested when the corolla was of the same length as the calyx or slightly longer. The developmental stage of the microspores was determined in microscopic slides of acetocarmine squashes. Flower buds were surface sterilized in $70 \%$ ethanol for several seconds, then in 5\% calcium hypochlorite $\mathrm{Ca}(\mathrm{ClO})_{2}+2-3$ drops Tween 20 for 10 minutes, and rinsed three times in sterile distilled water. After the removal of the filaments, anthers from three flower buds were placed in Petri dish $(6 \mathrm{~cm})$, with the concave face down, touching the culture medium. The method of Dumas de Valux et al. (1981) was used for induction of embryoid formation from pepper microspores [16]. The anthers were cultivated on $\mathrm{CP}$ medium + $0.01 \mathrm{mg} / \mathrm{l} \mathrm{KIN} \mathrm{+} 0.01 \mathrm{mg} / \mathrm{l} 2.4-\mathrm{D}$ with incubation of eight days in darkness at $35 \pm 2^{\circ} \mathrm{C}$, the following four days the anthers were transferred to clime chamber at $25 \pm 2^{\circ} \mathrm{C}$ with photoperiod of $12 \mathrm{~h}$ light/12 $\mathrm{h}$ dark. Afterwards, the anthers were subcultured on $R_{1}$ medium + $0.01 \mathrm{mg} / \mathrm{l} \mathrm{KIN}$ and placed in clime chamber at $25 \pm 2^{\circ} \mathrm{C}$ with photoperiodic $12 \mathrm{~h}$ light/12 $\mathrm{h}$ dark. Young embryoids emerging from the anthers were transferred onto hormone free V3 media for rooting. Plantlets were planted on sterile mixture of perlite : peat : sand (1:1:1) and acclimatized in clime chamber, and afterwards placed in greenhouse under cover in order to prevent 
crosspollination. The detailed description of applied methodology and the process of creation of androgenic genotypes is presented in different publications [10,17-19].

Each androgenic genotype under study (KK1, $\mathrm{KK} 2, \mathrm{P} 3, \mathrm{P} 4, \mathrm{~F} 5, \mathrm{~F} 6, \mathrm{~F} 7$ ) originated from the fruits of a distinct fertile androgenic plant. Hence, each androgenic genotype owns specific traits and a priory, each of them is unique, nevertheless they originate from an identical parental genotype.

During the first experimental year, seeds obtained from a fertile androgenic plant were utilized as starting material in the experiment. This procedure is applied for all seven androgenic genotypes under study. Seeds from a selected fruit from each androgenic genotype of the previous experimental year were used in the subsequent experimental years (Fig. 1a).

In this research seven pepper androgenic genotypes (KK1, KK2, P3, P4, F5, F6, F7) and their parental varieties Kurtovska kapia (KKk), Piran $(\mathrm{Pk})$ and Feherozon (Fk) were studied during four-years experiment in randomized block design in glasshouse conditions at the Faculty of Agriculture, Goce Delcev University Strumica, Republic of Macedonia (Fig. 1b). Each experimental year the seeds of studied genotypes were saw in the beginning of April in non-heated greenhouse. The seedlings were transplanted into pots $(\mathrm{d}=22 \mathrm{~cm})$ filled with mixture of soil, sand and peat (ratio 2:0.5:0.5). From each androgenic genotype and control genotypes, 40 plants (10 plants per replication) were placed in the greenhouse with distance of $30 \mathrm{~cm}$ in row and $100 \mathrm{~cm}$ between rows. Plants were cultivated according to standard cultivation practices under protected conditions. Irrigation and nutrition were performed as fertigation with drip system.

The varieties Kurtovska kapia, Piran and Feherozon, used as mother genotypes in anther culture, were used as controls (standards) of the androgenic genotypes (KK1, KK2, P3, P4, F5, F6, and F7). They were obtained from the gene bank of Faculty of Agriculture, Goce Delve University - Stip [18].

Kurtovska kapia is pepper variety mainly for industrial processing originated from Bulgaria. The plant height is $65 \mathrm{~cm}$, forming 2-3 basic branches and large leaves. The fruits are flattened triangular in shape with pendant position. The average period to horticulturally maturity of fruits is 120 and to physiological maturity is $145-150$ days, with average yields of $50 \mathrm{t} / \mathrm{ha}$ in open field production [10].

Piran is Macedonian variety which can be cultivated in open field and under protected conditions. The average plant height is $80 \mathrm{~cm}$, fruits are large with average weight of $100-120 \mathrm{~g}$, yellow in unripe stage and red when ripe. Piran average yield is $60-80 \mathrm{t} / \mathrm{ha}[10,20]$.

Feherozon is Hungarian variety for production in open fields and protected conditions with average plant height of $35-40 \mathrm{~cm}$. It is in the group of blocky fruit shape with erect position on the stem, with white yellowish colour in technological maturity and light red in physiological maturity. Average yield under protected conditions is $6-8 \mathrm{~kg} / \mathrm{m} 2$ and $25-35 \mathrm{t} / \mathrm{ha}$ in open field conditions [10].
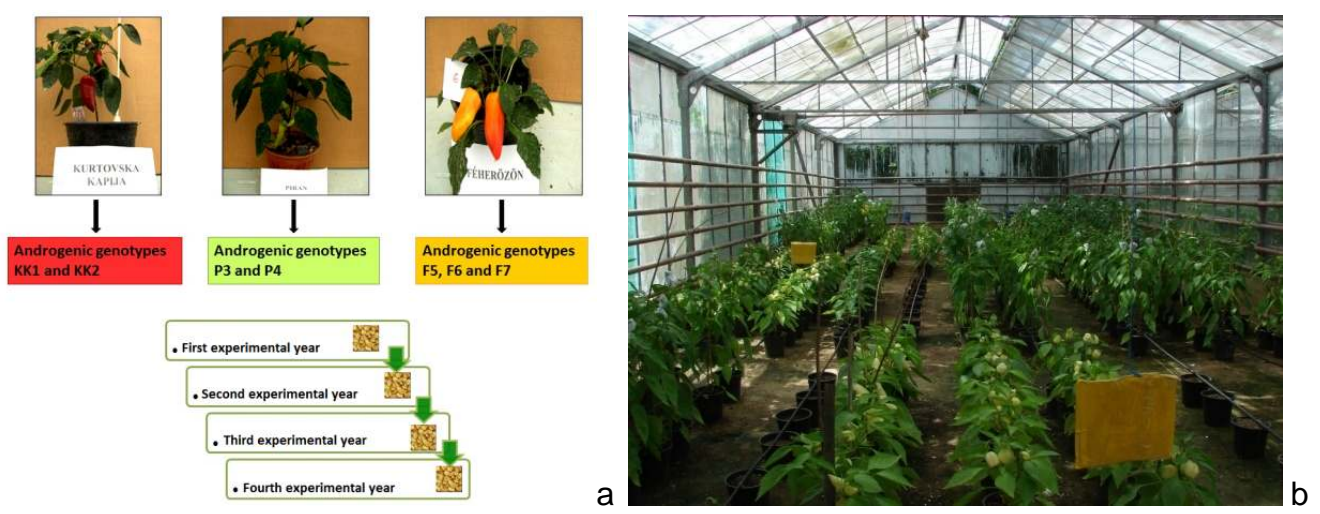

Fig. 1. Experimental design. a) Androgenic pepper genotypes and their parental genotypes in randomized block design in the experimental greenhouse. b) Randomized block design of the experiment 
Reproductive data were collected at flowering and fruiting stages of vegetation according to the guidelines given in Descriptors for Capsicum (Capsicum spp.) [9].

During the experiment the reproductive phenophases and their duration were observed and analyzed [9]:

- Days to seedling emergence - number of days to $50 \%$ emergence of seedlings;

- Days to flowering - number of days from transplanting until $50 \%$ of plants have at least one open flower;

- Days to fruiting - number of days from transplanting until $50 \%$ of the plants bear fruits;

- Days to horticulturally mature fruits number of days from transplanting until $50 \%$ of the plants bear mature fruits in intermediate stage;

- Days to physiologically mature fruits number of days from transplanting until $50 \%$ of the plants bear mature fruits in ripening stage.

From each genotype under study, five (5) plants per replication were labeled for collection of following data [9]:

- Number of flowers per plant;

- Number of fertilized flowers per plant;

The number of flowers and the number of fertilized flowers were count for three days during early morning hours, starting from the day when $50 \%$ of plants have at least one open flower or $50 \%$ of the plants bear fruits.

From each genotype under study, ten (10) fruits per replication were labeled for collection of following data [9]:

- Number of seeds per fruit;

- Weight of seed per fruit (g).

\subsection{Biometric Analysis of Characteristics}

Statistical analysis of variance is applied for the evaluation of the experiment in general and each of the characteristics among all tested genotypes (One-Way ANOVA test) with IBM SPSP Statistics Software 19.0.

For evaluation of the difference between examined genotypes Duncan's multiple range test is utilized for each trait in each experimental year on $0.05 \%$ and for the four-year average on level $0.05 \%$ and $0.01 \%$. The Pearson's correlation coefficient was used to show the statistical association and dependence among reproductive traits of genotypes under research. Pearson's correlation coefficient was estimated on level $0.05 \%$ and $0.01 \%$.

\section{RESULTS AND DISCUSSION}

\subsection{Emergence of Seedlings}

Seed germination and seedling emergence are critical for successful stand establishment and crop yield of peppers [21]. As thermophile crop, peppers maximum need for heat is in the phase of germination and seedlings emergence. Minimum temperature for emergence is $10^{\circ} \mathrm{C}$, but the seeds germinate after 35 days. When the soil or substrate temperature is $22-25^{\circ} \mathrm{C}$, the emergence starts after 6-7 days. Peppers have a prolonged germination period and an optimum germination temperature of about $30^{\circ} \mathrm{C}$ [6].

Mean number of days to emergence of seedlings during the four-years experiment is given in Fig. 2. For Kurtovska kapia genotypes, including the control (17.5 days) 16.25 (KK1) to 17.5 (KK2) days were needed for emergence of plantlets, while for Piran genotypes, 15.25 days (P3), 17 days (P4) and 18 days (Pk). Plantlets of androgenic lines F5, F6 and F7 emerged for 13 days, which is significantly earlier as compared to the control Feherozon (16 days to emergence). Extended time of 13-18 days for seedling emergence of pepper genotypes under research was due low substrate temperatures because the seeds were sow in the beginning of April in unheated greenhouse. The rate of germination and emergence was markedly reduced at temperatures in the range of $15-20^{\circ} \mathrm{C}$ which is consistent with our findings [2].

\subsection{Length of Vegetation Period to Flowering and Fruiting}

Pepper flowering is the most intensive during morning hours, and the intensity drops in midday and afternoon, and again intensifies in the late afternoon hours [6]. In peppers, phenophase flowering is 65 to 70 days after seedling emergence. It is dependent on genetic characteristics of genotype and on cumulative effect of complex abiotic factors as day length, where with increasing of day length over 14 hours a disproportion is between vegetative and generative organs in advantage of vegetative [22]. 


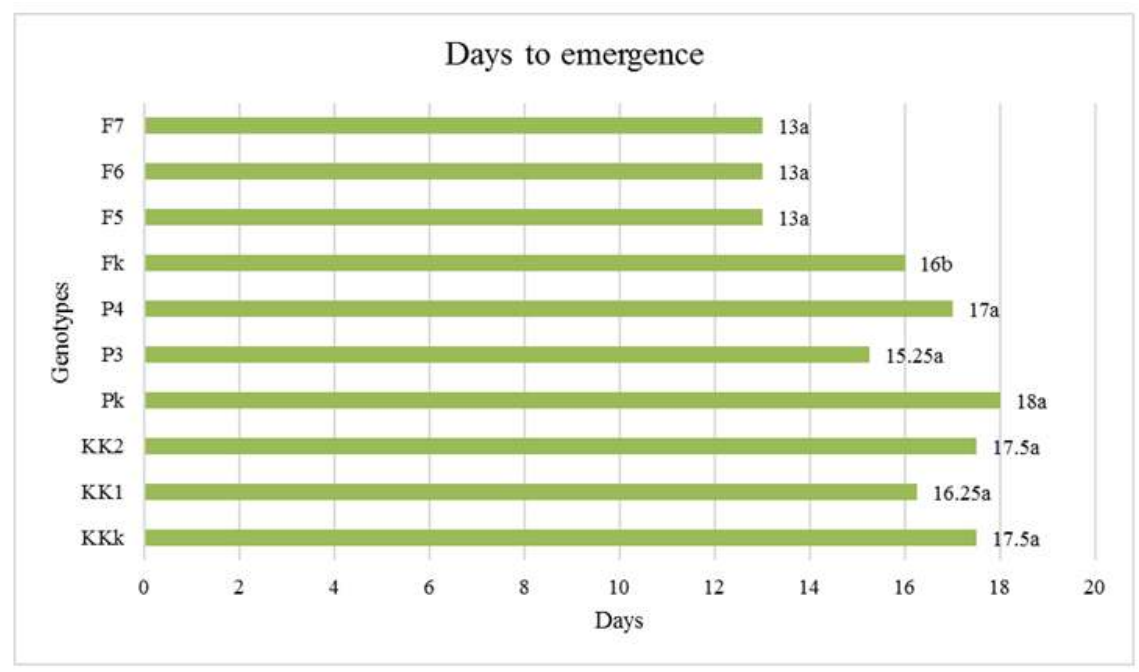

Fig. 2. Number of days to seedling emergence for all genotypes under research

Mean separation in figure columns by Duncan's multiple range test. In each figure column, values followed by the same letter do not differ significantly at $P<0.05$ and values followed by the same number do not differ significantly at $P<0.01$

During four-year experiment, androgenic genotypes and their mother genotypes showed certain duration of flowering and fruiting phenophase. The four-years mean values of these phenophases are presented in figures below.

The KK1 and KK2 genotypes have 46.3 and 46.5 days to flowering, respectively, while the control KKk 76 days. In addition, number of days to fruiting was 56.5 days (Kurtovska kapia, control), 57.8 days (KK1) and 54.6 days (KK2) (Fig. 3). Androgenic genotype P3 and P4 have 43.8 and 46.5 days to flowering, respectively, while the control Piran 37.5 days. Furthermore, number of days to fruiting was 59.3 days (P3 and P4) and 55.5 days (Piran, control) (Fig. 4). Androgenic genotype F5 had 35 days period to flowering, while F6 and F7, 33 and 33.8 days respectively. The mean day to flowering for the control genotype Feherozon was 35.8 days. Moreover, the shortest fruiting period was recorded for F6 (45.5 days), the longest for F5 (48.3 days). The length of 47.3 days to fruiting was the same for the control Feherozon and androgenic genotype F7 (Fig. 5).

Under greenhouse conditions, 17 pepper genotypes showed 44 days to $50 \%$ flowering and 48 days to first fruit set [23]. Other authors reported heterotic crosses of high frequency over better parent and standard check for days to first flowering, days to first harvest, growth and yield traits [24,25]. These findings are in disagreement with ours because our results have not shown significant difference between parent genotypes and androgenic lines.

According to [26], high heritability and high genetic advance were recorded for average fruit weight, fruit yield per plant, fruit diameter, and number of lobes per fruit, days to first harvest, leaf area and ascorbic acid content indicating the role of additive gene action for the inheritance of these traits. At genotypic levels, the traits fruit length, fruit diameter and number of fruits per plant revealed significant positive correlation with fruit yield per plant. Number of fruits per plant exhibited the highest positive direct effect followed by average fruit weight, number of branches per plant, pedicel length and harvest duration at genotypic level.

\subsection{Length of Vegetation Period to Horticultural Fruit Maturity and Physiological Fruit Maturity}

The vegetation length to horticultural and physiological maturity of fruits in different pepper varieties has different duration depending on agroecological conditions and applied cultivation practices. Different authors reported different vegetation length of pepper varieties. The vegetation length of pepper varieties (Capsicum annuum L.) to horticultural maturity is 95-115 days, while to physiological maturity 143 days 
[27]. On the other hand, other author has classified peppers according to their earliness as early peppers with 120 days vegetation period from germination to physiological maturity, medium early peppers with 121 to 140 days and late peppers with vegetation period longer than 140 days [7].

The length of vegetation period to horticultural fruit maturity of $\mathrm{KK} 1$ and $\mathrm{KK} 2$ androgenic genotypes was 97.5 and 96.5 days respectively, while the length to physiological fruit maturity was 121 day for both genotypes. Compared to the length of phenophase to physiological maturity for control, genotypes $\mathrm{KK} 1$ and $\mathrm{KK} 2$ were 5.7 days earlier than the control Kurtovska kapia (Fig. 3).

Androgenic genotypes P3 and P4 have 95.3 and 94 days, respectively, vegetation period length to physiological maturity, accordingly $\mathrm{P} 4$ was one day earlier than the mother genotype Piran. For genotypes derived from variety Piran, the length of vegetation period to horticultural maturity is more important because fruits are more utilized when in horticultural maturity. The length of this period was 73 days (P3 genotype) and 72.5 days (P4 genotype) and compared to the control Piran they were earlier for 0.5 day (P3 genotype) and 1 day (P4 genotype) (Fig. 4).

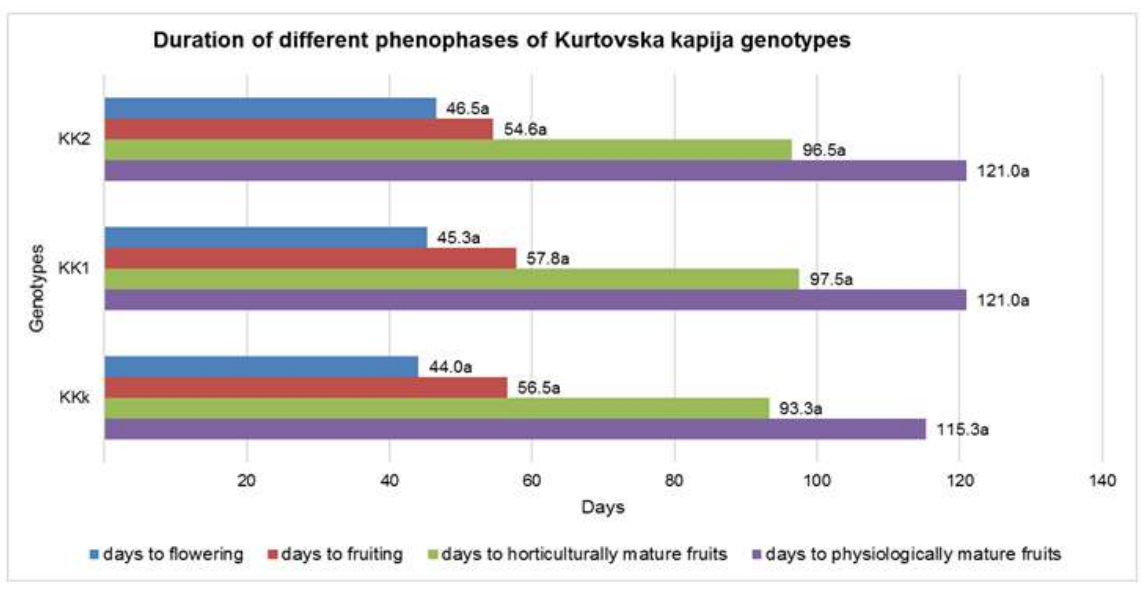

Fig. 3. Duration of different phenophases of Kurtovska kapia genotypes

Mean separation in figure columns by Duncan's multiple range test. In each figure column, values followed by the same letter do not differ significantly at $P<0.05$ and values followed by the same number do not differ significantly at $P<0.01$

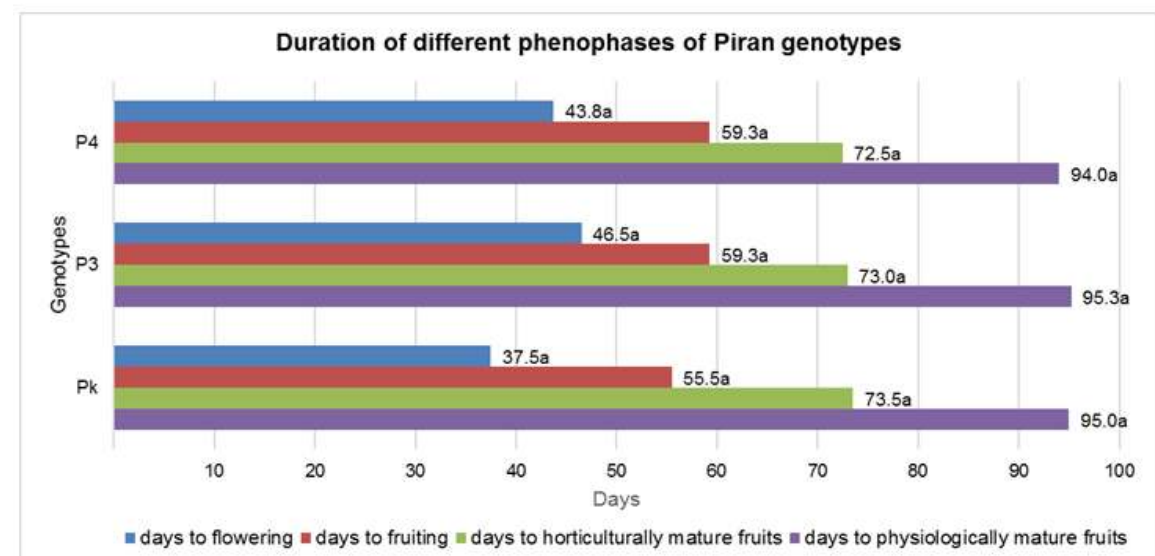

Fig. 4. Duration of different phenophases of Piran genotypes

Mean separation is shown in figure columns by Duncan's multiple range test. In each figure column, values followed by the same letter do not differ significantly at $P<0.05$ and values followed by the same number do not differ significantly at $P<0.01$ 
Fruits of variety Feherozon and its androgenic genotypes can be used in horticultural and physiological maturity which means that lengths of both phenophases are important when cultivating such varieties. Fruits of androgenic F5 needed 74.3 days to reach horticultural fruit maturity, F6 genotype 74 days and 73 days for F7. When compared to the number of days to horticultural maturity of control Feherozon, the androgenic genotypes had 5.3 days (F5), 5 days (F6) and 4 days (F7) longer horticultural maturity phenophase. The number of days to physiologically mature fruits was 96 days (F5), 95.8 days (F6) and 94.8 days (F7). All Feherozon derived androgenic genotypes have 4.5 to 6 days longer phenophase to physiologically mature fruits compared to the control Feherozon without statistically proven difference (Fig. 5).

According to [23] number of days to first fruit ripening under field conditions varied 56 days to 87 days, while it was 57 days to 108 for peppers tested under greenhouse conditions for 17 pepper genotypes. Different days needed for horticultural and physiological fruit maturity are due to differences in genetic inheritance and environmental conditions. Phenotypic variation indicated higher values than genotypic variation for many traits including days to $50 \%$ flowering and harvest duration, indicating close association between phenotype and genotype [28].

\subsection{Reproductive Traits of Androgenic Genotypes and Their Mother Genotypes}

Different androgenic genotypes showed variation in flower number and flower fertilization in different experimental years and on four-year experimental level.

Average number of 7.56 flowers per plant for KK1 genotype was significantly lower than flower number of KK2 (16.47 flowers) and control Kurtovska kapia (14.43 flowers). During I, II and III experimental year androgenic line KK1 had significantly lower number of flowers compared to KK2 and the mother genotype Kurtovska kapia. The four-years mean number of fertilized flowers was 3.79 (KK2), 5.60 (KK1) and 5.21 (control Kurtovska kapia). The number of fertilized flowers varied during the research period, thus in I and II experimental year, the higher number of fertilized flowers was recorded for androgenic genotypes KK2, while in III and IV year for the control genotype (Table 1). The average number of seed pre fruit for androgenic genotypes KK1 and KK2 compared to the control genotype Kurtovska kapia for all research period showed that there was a significant difference between KK1 (197.11 seeds per fruit) and the control (229.60 seeds per fruit). In III experimental year KK1 (200.80 seeds per fruit) showed statistically less seed than the control (226.10 seeds per fruit), while in IV experimental year, significantly different were the number of seeds per fruit of KK2 androgenic genotype (190.25 seeds) compared to the control (235.70 seeds). The trait weight of seeds per fruit for all research period had the highest mean values for KK2 $(1.57 \mathrm{~g})$ and the lowest for KK1 $(1.14 \mathrm{~g})$, while the average seed weight of the control Kurtovska kapia was $1.46 \mathrm{~g}$.

In Table 2 are presented the results for number of flowers and number of fertilized flowers for androgenic genotypes P3 and P4 and their control genotype. During the four-years research period, the number of flowers varied from 20.65 flowers as the highest mean number (P3, II experimental year) to 6.67 flowers as the lowest mean value (P4, IV experimental year). Number of flowers per plant varied from 9.17 to 15.80 for the control Piran. During whole experimental period, P3 androgenic genotype had averagely 16.00 flowers which was significantly higher compared to 11.81 flowers (P4 genotype) and 12.89 flowers (control Piran). Androgenic genotypes were characterized with averagely 5.81 (P3) and 5.29 (P4) fertilized flowers during the whole experimental period without significant difference compared to the control Piran (6.56 fertilized flowers). Piran derived androgenic genotypes have showed statistically significant difference for the trait number of seeds per fruit in all research years, except in the first one. During the whole experimental period, the control Piran had significantly more seeds per fruit (182.57) than the androgenic lines P3 (144.13 seeds per fruit) and P4 (144.06 seeds per fruit). The highest mean weight of seeds per fruit was measured for P3 genotype (1.35 g), while the lowest for P4 $(0.51 \mathrm{~g})$. The mean values of this trait for all research period recorded for P3 (1.12 g) and P4 $(1.05 \mathrm{~g})$ androgenic genotypes statistically were in the same group of significance with the control Piran (0.97 g).

During four years experiment, 14.10 flowers per plant as the highest mean number of flowers was recorded for androgenic genotype F5 while the lowest mean number of flowers was registered for the control genotype Feherozon. The variation of mean number of flowers among all Feherozon genotypes under study was not 
statistically proven in I and II experimental year. In III experimental year androgenic genotypes F5 and F7 had higher number of flowers compared to genotype F6 and significantly more flowers compared to the control, while in the last experimental year the genotypes F5 had significantly more flowers than the other Feherozon genotypes. The average number of fertilized flowers was statistically different among tested Feherozon genotypes. During four-years experiment, the number of fertilized fruit varied from the lowest 4.19 (control Feherozon) to highest 6.31 for androgenic line F7. The trait seed number per fruit in I and II experimental year was significantly different between androgenic lines and to the control Piran. The highest seed number per fruit was registered in control fruits (330.80 seeds, II experimental year), while the lowest in androgenic genotypes F6 (103.53 seeds, I experimental year). During the whole experimental period, the mean value of seed weight per fruit of Feherozon androgenic genotypes was significantly lower compared to the control Feherozon (1.35 g).

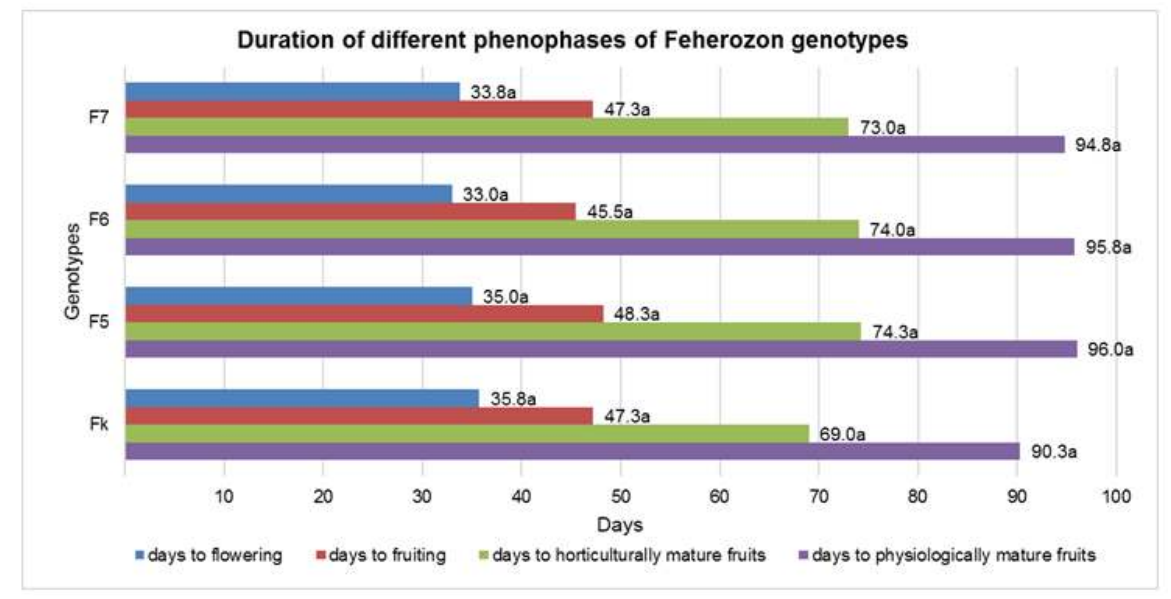

Fig. 5. Duration of different phenophases of Feherozon genotypes

Mean separation is shown in figure columns by Duncan's multiple range test. In each figure column, values followed by the same letter do not differ significantly at $P<0.05$ and values followed by the same number do not differ significantly at $P<0.01$

Table 1. Reproductive traits of Kurtovska kapia genotypes

\begin{tabular}{|c|c|c|c|c|c|}
\hline $\begin{array}{l}\text { Experimental } \\
\text { year }\end{array}$ & Genotype & $\begin{array}{l}\text { Number of } \\
\text { flowers }\end{array}$ & $\begin{array}{l}\text { Number of } \\
\text { fertilized } \\
\text { flowers }\end{array}$ & $\begin{array}{l}\text { Number of } \\
\text { seeds per } \\
\text { fruit }\end{array}$ & $\begin{array}{l}\text { Weight of } \\
\text { seeds per } \\
\text { fruit (g) }\end{array}$ \\
\hline & KKk & $17.00 \mathrm{a}$ & $3.20 \mathrm{~b}$ & $203.27 a$ & $1.44 a$ \\
\hline \multirow{3}{*}{-} & KK1 & $6.25 b$ & $3.90 \mathrm{~b}$ & $208.05 a$ & $1.32 \mathrm{a}$ \\
\hline & KK2 & $16.50 \mathrm{a}$ & $5.70 a$ & $198.25 a$ & $1.61 \mathrm{a}$ \\
\hline & $\mathrm{KKk}$ & $18.80 \mathrm{a}$ & $4.10 \mathrm{~b}$ & $202.4 a$ & $1.38 a b$ \\
\hline \multirow[t]{3}{*}{$=$} & KK1 & $7.15 b$ & $3.20 \mathrm{~b}$ & $175.8 \mathrm{a}$ & $1.18 b$ \\
\hline & KK2 & $18.00 \mathrm{a}$ & $6.10 a$ & $226.1 a$ & $1.65 a$ \\
\hline & KKk & $18.90 \mathrm{a}$ & $7.70 a$ & $263.90 a$ & $1.50 \mathrm{a}$ \\
\hline \multirow[t]{3}{*}{$\equiv$} & KK1 & $8.75 b$ & $5.45 a b$ & $200.80 \mathrm{~b}$ & $0.92 b$ \\
\hline & KK2 & $10.95 b$ & $5.60 a b$ & $242.70 a b$ & $1.61 \mathrm{a}$ \\
\hline & $\mathrm{KKk}$ & $7.67 a$ & $4.33 a$ & $235.70 a$ & $1.52 \mathrm{a}$ \\
\hline \multirow{2}{*}{$\geq$} & KK1 & $8.42 a$ & $3.20 a$ & $203.80 \mathrm{ab}$ & $1.16 \mathrm{~b}$ \\
\hline & KK2 & $10.83 a$ & $1.00 \mathrm{~b}$ & $190.25 b$ & $1.17 \mathrm{~b}$ \\
\hline Average I-IV & $\mathrm{KKk}$ & $16.47^{a, 2}$ & $5.21^{\mathrm{a}, 2}$ & $229.60^{\mathrm{a}, 2}$ & $1.46^{\mathrm{a}, 2}$ \\
\hline Average I-IV & KK1 & $7.56^{\mathrm{b}, 1}$ & $5.60^{a, 2}$ & $197.11^{\mathrm{b}, 1}$ & $1.14^{\mathrm{b}, 1}$ \\
\hline Average I-IV & KK2 & $14.43^{a, 2}$ & $3.79^{\mathrm{b}, 1}$ & $221.39^{\mathrm{a}, 1,2}$ & $1.57^{\mathrm{a}, 2}$ \\
\hline
\end{tabular}


Table 2. Reproductive traits of Piran genotypes

\begin{tabular}{llllll}
\hline $\begin{array}{l}\text { Experimental } \\
\text { year }\end{array}$ & Genotype & $\begin{array}{l}\text { Number of } \\
\text { flowers }\end{array}$ & $\begin{array}{l}\text { Number of } \\
\text { fertilized } \\
\text { flowers }\end{array}$ & $\begin{array}{l}\text { Number of } \\
\text { seeds per } \\
\text { fruit }\end{array}$ & $\begin{array}{l}\text { Weight of } \\
\text { seeds per } \\
\text { fruit (g) }\end{array}$ \\
\hline & & $14.70 \mathrm{a}$ & $4.20 \mathrm{a}$ & $138.40 \mathrm{a}$ & $0.77 \mathrm{~b}$ \\
- & $\mathrm{Pk}$ & $18.70 \mathrm{a}$ & $3.85 \mathrm{a}$ & $124.2 \mathrm{a}$ & $1.35 \mathrm{a}$ \\
& $\mathrm{P} 3$ & $13.45 \mathrm{a}$ & $3.75 \mathrm{a}$ & $126.45 \mathrm{a}$ & $1.14 \mathrm{ab}$ \\
& $\mathrm{P} 4$ & $15.80 \mathrm{a}$ & $4.10 \mathrm{a}$ & $235.20 \mathrm{a}$ & $1.31 \mathrm{ab}$ \\
$=$ & $\mathrm{Pk}$ & $20.65 \mathrm{a}$ & $4.15 \mathrm{a}$ & $146.85 \mathrm{~b}$ & $1.10 \mathrm{~b}$ \\
& $\mathrm{P3}$ & $14.90 \mathrm{a}$ & $4.00 \mathrm{a}$ & $181.40 \mathrm{~b}$ & $1.45 \mathrm{a}$ \\
& $\mathrm{P} 4$ & $10.40 \mathrm{a}$ & $8.40 \mathrm{a}$ & $197.40 \mathrm{a}$ & $0.96 \mathrm{a}$ \\
三 & $\mathrm{Pk}$ & $11.20 \mathrm{a}$ & $9.20 \mathrm{a}$ & $159.50 \mathrm{~b}$ & $1.06 \mathrm{a}$ \\
& $\mathrm{P3}$ & $9.40 \mathrm{a}$ & $8.10 \mathrm{a}$ & $160.25 \mathrm{~b}$ & $1.10 \mathrm{a}$ \\
$\geq$ & $\mathrm{P}$ & $9.17 \mathrm{a}$ & $11.50 \mathrm{a}$ & $159.30 \mathrm{a}$ & $0.85 \mathrm{a}$ \\
& $\mathrm{Pk}$ & $10.33 \mathrm{a}$ & $6.33 \mathrm{~b}$ & $146.60 \mathrm{ab}$ & $0.95 \mathrm{a}$ \\
Average I-IV & $\mathrm{P} 3$ & $6.67 \mathrm{a}$ & $5.33 \mathrm{~b}$ & $108.20 \mathrm{~b}$ & $0.51 \mathrm{~b}$ \\
Average I-IV & $\mathrm{Pk}$ & $12.89^{\mathrm{b}, 12}$ & $6.56^{\mathrm{a}, 1}$ & $182.57^{\mathrm{a}, 2}$ & $0.97^{\mathrm{a}, 1}$ \\
Average I-IV & $\mathrm{P} 4$ & $16.00^{\mathrm{a}, 2}$ & $5.81^{\mathrm{a}, 1}$ & $144.13^{\mathrm{b}, 1}$ & $1.12^{\mathrm{a}, 1}$ \\
\hline
\end{tabular}

Mean separation is shown in columns by Duncan's multiple range test. Values followed by the same letter do not differ significantly at $P<0.05$ and values followed by the same number do not differ significantly at $P<0.01$

Table 3. Reproductive traits of Feherozon genotypes

\begin{tabular}{|c|c|c|c|c|c|}
\hline $\begin{array}{l}\text { Experimental } \\
\text { year }\end{array}$ & Genotype & $\begin{array}{l}\text { Number of } \\
\text { flowers }\end{array}$ & $\begin{array}{l}\text { Number of } \\
\text { fertilized } \\
\text { flowers }\end{array}$ & $\begin{array}{l}\text { Number of } \\
\text { seeds per } \\
\text { fruit }\end{array}$ & $\begin{array}{l}\text { Weight of } \\
\text { seeds per } \\
\text { fruit (g) }\end{array}$ \\
\hline \multirow{4}{*}{ - } & Fk & $9.70 a$ & $3.90 \mathrm{~b}$ & $173.80 \mathrm{a}$ & $0.98 a$ \\
\hline & F5 & $8.85 a$ & $4.55 b$ & 140.74ab & $0.85 a b$ \\
\hline & F6 & $9.15 a$ & $4.70 \mathrm{~b}$ & $103.53 b$ & $0.59 \mathrm{~b}$ \\
\hline & F7 & $10.85 a$ & $6.10 a$ & 119.72ab & $0.67 a b$ \\
\hline \multirow{4}{*}{$=$} & Fk & $11.08 \mathrm{a}$ & $4.10 \mathrm{~b}$ & $330.80 a$ & $1.85 \mathrm{a}$ \\
\hline & F5 & $9.85 a$ & $5.00 \mathrm{~b}$ & $223.75 b$ & $1.30 \mathrm{~b}$ \\
\hline & F6 & $10.05 a$ & $5.40 \mathrm{~b}$ & $211.90 b$ & $1.15 \mathrm{~b}$ \\
\hline & F7 & $11.00 \mathrm{a}$ & $6.90 a$ & $227.05 b$ & $1.25 b$ \\
\hline \multirow{4}{*}{$\equiv$} & Fk & $14.80 \mathrm{~b}$ & $4.20 \mathrm{~b}$ & $234.50 a$ & $1.19 a$ \\
\hline & F5 & $19.60 \mathrm{a}$ & $6.55 a$ & $264.70 a$ & $1.30 a$ \\
\hline & F6 & 17.25ab & $5.20 a b$ & $252.35 a$ & $1.39 a$ \\
\hline & F7 & $20.60 a$ & $5.55 a b$ & $223.35 a$ & $1.35 a$ \\
\hline \multirow{4}{*}{$\geq$} & $\mathrm{Fk}$ & $11.33 \mathrm{~b}$ & $4.83 \mathrm{~b}$ & $233.00 a$ & $1.19 a$ \\
\hline & F5 & $20.75 a$ & $8.92 a$ & $169.80 a$ & $0.89 a$ \\
\hline & F6 & $11.09 \mathrm{~b}$ & $6.17 \mathrm{~b}$ & $234.70 a$ & $1.25 \mathrm{a}$ \\
\hline & F7 & $12.91 \mathrm{~b}$ & $6.92 a b$ & $204.50 a$ & $1.04 a$ \\
\hline Average I-IV & Fk & $11.72^{\mathrm{b}, 1}$ & $4.19^{\mathrm{c}, 1}$ & $252.91^{\mathrm{a}, 2}$ & $1.35^{\mathrm{a}, 1}$ \\
\hline Average I-IV & F5 & $14.10^{\mathrm{a}, 1}$ & $5.96^{\mathrm{ab}, 2}$ & $200.49^{b, 1}$ & $1.08^{\mathrm{b}, 1}$ \\
\hline Average I-IV & F6 & $11.99^{\mathrm{ab}, 1}$ & $5.28^{\mathrm{b}, 2}$ & $201.85^{\mathrm{b}, 1}$ & $1.1^{\mathrm{b}, 1}$ \\
\hline Average I-IV & F7 & $12.96^{\mathrm{ab}, 1}$ & $6.31^{\mathrm{a}, 2}$ & $195.55^{\mathrm{b}, 1}$ & $1.08^{\mathrm{b}, 1}$ \\
\hline
\end{tabular}

In the available literature, there is no research data about number of flowers, number of fertilized flowers, and number of seeds per fruit and weight of seeds per fruit of androgenic genotypes. However, regarding number of flowers fertilization our results are in agreement with flowers fertilization percentage of pepper reported by $[29,30]$.

Pepper fruiting depends on genetic predisposition, agroecological conditions and cultivation practices. The best flower fertilization 
is between 10 and 14 hours and it is proved that the most seeds in the fruit are set when the fertilization happened in that time [6]. The air temperature has the biggest effect on pepper fertilization process because it has direct influence on pollen formation and its viability. Other authors state that air temperature higher than $30^{\circ} \mathrm{C}$ in flowering phenophase cause pollen sterility, while night temperatures from $10 \pm 2^{\circ} \mathrm{C}$ decrease number and germination of pollen grains. When temperatures are higher than optimum $20-25^{\circ} \mathrm{C}$, there is a process of flower abortion because of higher transpiration [31]. Also, earliness or lateness in the days to $50 \%$ flowering could be due to their inherited characters and the early adaptation to the growing environment to enhance their growth and development [32] and earliness to flowering and fruiting is related to variety differences [33].

\subsection{Estimation of Correlation Coefficients among Reproductive Traits of Pepper Genotypes}

The results for estimation of correlation coefficients among eight traits in androgenic genotypes derived from Kurtovska kapia and the control are presented in Table 4.

The trait days to flowering was positive and significantly associated with the traits days to fruiting, days to horticulturally mature fruits, days to physiologically mature fruits, and number of fertilized flowers. The trait days to fruiting were positively and significantly associated with the traits days to horticulturally mature fruits and days to physiologically mature fruits. Furthermore, the trait days to horticulturally mature fruits was significantly and positively correlated to days to physiologically mature fruits. Number of seeds per fruit was significantly and positively correlated with number of fertilized fruits.

For crop improvement purposes selection for the traits days to flowering and days to fruiting, will contribute to pepper earliness, thus it will increase the economic value of Kurtovska kapia genotypes. In chili peppers, the trait days to $50 \%$ fruiting maximize fruit length, fruit width, lycopene content, antioxidant activity, flavonoid content and number of fruits [23].

The results for estimation of correlation coefficients among eight traits in androgenic genotypes derived from Piran and the control are presented in Table 5. Positive and significant association was observed between traits days to flowering and days to horticulturally mature fruits; traits days to fruiting and weight of seeds per fruit; and traits days to horticulturally mature fruits and days to physiologically mature fruits. Piran genotypes under this research showed the less association of traits as compared to other studied genotypes. However, days to flowering are a key trait for future breeding programmes for earliness of these genotypes [22].

The results of the analysis for estimation of traits correlation of androgenic genotypes derived from Feherozon and the control showed the highest association (Table 6). The trait days to flowering was positively and significantly correlated with the traits days to flowering, days to horticulturally and physiologically mature fruits, and in negative correlation with the trait number of flowers. The trait days to fruiting were in either positive or negative correlation with all analyzed traits

Table 4. Correlation between biological traits of Kurtovska kapia genotypes

\begin{tabular}{|c|c|c|c|c|c|c|c|c|}
\hline & DtFI & DtFr & DtHMF & DtPMF & NoF & NoFF & NoSF & WoSF \\
\hline$\overline{\mathrm{DtFI}}$ & - & & & & & & & \\
\hline DtFr & $0.914^{\star *}$ & & & & & & & \\
\hline DtHMF & $0.936^{\star *}$ & $0.894^{\star *}$ & & & & & & \\
\hline DtPMF & $0.817^{\star \star}$ & 0.779 ** & $0.931^{\star *}$ & & & & & \\
\hline NoF & 0.356 & 0.235 & 0.193 & 0.077 & & & & \\
\hline NoFF & $0.619^{*}$ & 0.571 & 0.461 & 0.377 & 0.451 & & & \\
\hline NoSF & 0.076 & 0.025 & -0.158 & -0.174 & 0.176 & $0.632^{*}$ & & \\
\hline WoSF & 0.106 & 0.205 & -0.068 & -0.156 & 0.225 & 0.227 & 0.547 & - \\
\hline
\end{tabular}


Table 5. Correlation between biological traits of Piran genotypes

\begin{tabular}{|c|c|c|c|c|c|c|c|c|}
\hline & DtFI & DtFr & DtHMF & DtPMF & NoF & NoFF & NoSF & WoSF \\
\hline$\overline{\mathrm{DtFl}}$ & - & & & & & & & \\
\hline DtFr & $0.727^{\star \star \star}$ & & & & & & & \\
\hline DtHMF & 0.510 & 0.357 & & & & & & \\
\hline DtPMF & $0.647^{*}$ & 0.567 & $0.948^{\star *}$ & & & & & \\
\hline NoF & 0.200 & $0.676^{\star}$ & 0.092 & 0.237 & & & & \\
\hline NoFF & 0.077 & -0.498 & -0.015 & -0.130 & -0.726 & & & \\
\hline NoSF & 0.170 & 0.136 & -0.236 & -0.038 & -0.063 & 0.205 & & \\
\hline WoSF & 0.571 & $0.775^{\star \star}$ & 0.006 & 0.257 & 0.429 & -0.226 & 0.574 & - \\
\hline $\begin{array}{r}D \\
\text { hysio }\end{array}$ & flowe & $\begin{array}{r}D t F I) ; D a \\
\text { uits (DtP } \\
\text { seeds } \\
{ }^{* \star} C \\
{ }^{*} C\end{array}$ & $\begin{array}{l}\text { r fruit (No } \\
\text { lation is } \\
\text { lation is }\end{array}$ & $\begin{array}{l}\text {-); Weight } \\
\text { nificant at } \\
\text { nificant at }\end{array}$ & $\begin{array}{l}\text { horticult } \\
\text { F); Numl } \\
\text { seeds p } \\
0.01 \text { lev } \\
0.05 \text { lev }\end{array}$ & $\begin{array}{l}\text { y mature } \\
\text { ff fertilize } \\
\text { uit (WoSt } \\
\text { 2-tailed). } \\
\text { 2-tailed) }\end{array}$ & $\begin{array}{l}\text { ts (DtHn } \\
\text { owers ( }\end{array}$ & $\begin{array}{l}\text { Days to } \\
\text { ); Numb }\end{array}$ \\
\hline
\end{tabular}

Table 6. Correlation between biological traits of Feherozon genotypes

\begin{tabular}{|c|c|c|c|c|c|c|c|c|}
\hline & DtFI & DtFr & DtHMF & DtPMF & NoF & NoFF & NoSF & WoSF \\
\hline$\overline{\mathrm{DtFl}}$ & - & & & & & & & \\
\hline $\mathrm{DtFr}$ & $0.851^{\star *}$ & & & & & & & \\
\hline DtHMF & $0.640^{\star \star}$ & $0.781^{\star \star}$ & & & & & & \\
\hline DtPMF & $0.551^{*}$ & $0.720^{\star \star}$ & $0.975^{\star \star}$ & & & & & \\
\hline NoF & $-0.593^{\star}$ & $-0.711^{\star *}$ & -0.492 & -0.444 & & & & \\
\hline NoFF & -0.437 & -0.342 & -0.329 & -0.303 & $0.504^{\star}$ & & & \\
\hline NoSF & -0.158 & $-0.517^{\star}$ & $-0.598^{\star}$ & $-0.540^{\star}$ & 0.441 & 0.076 & & \\
\hline WoSF & -0.045 & -0.189 & -0.157 & -0.169 & 0.228 & 0.079 & $0.505^{\star}$ & - \\
\hline
\end{tabular}

except weight of seeds per fruit. The trait days to horticulturally mature fruits was in significant positive correlation with days to physiologically mature fruits, while the trait number of seeds per fruit was in negative correlation with traits days to horticulturally and physiologically mature fruits. The trait number of flowers was in positive correlation with number of fertilized flowers. In order to improve the earliness of these genotypes, selection for fewer days to flowering and fruiting should be taken into account. The negative correlation of number of seeds per fruit with three fruit important characteristics provides useful information for breeders if breeding for improvement of flesh/seeds ratio [4,22,34].

\section{CONCLUSION}

There is an extended time for seedling emergence of all pepper genotypes due to applied cultivation practices. The androgenic genotypes KK1 and KK2 were 5.7 days earlier than the control Kurtovska kapia. The genotypes P3 and P4 were 0.5 and 1 day earlier than the control Piran in horticultural fruit maturation, while all Feherozon derived androgenic genotypes were 4.5 to 6 days later than the control in physiological fruit maturation.

Therefore, according to the phenophase length to horticultural and physiological maturity (pepper earliness), androgenic genotypes under study belong to different peppers:

- $\quad$ Androgenic genotypes KK1 and KK2 - late maturity pepper genotypes;

- Androgenic genotypes P3 and P4 medium early pepper genotypes and

- Androgenic genotypes F5, F6 and F7 medium early pepper genotypes.

Furthermore, there is a significant and positive association of days to flowering and days to fruiting with days to horticultural and physiological fruit maturity. These androgenic genotypes are valuable breeding resources for improvement of earliness and other traits of sweet pepper genotypes to satisfy the needs of 
pepper producers and consumers. Finally, this is a contribution to absence of research of reproductive traits in androgenic pepper genotypes.

\section{COMPETING INTERESTS}

Authors have declared that no competing interests exist.

\section{REFERENCES}

1. Kang BC, Kole C, editors. Genetics. Genomics and breeding of peppers and eggplants. Boca Raton: CRC Press; 2013.

2. Bosland PW, Votava EJ. Peppers: Vegetable and spice capsicums. New York: CABI Publishing; 2000.

3. Abu-Zahra TR. Vegetative flowering and yield of sweet pepper as influenced by agricultural practices. Middle-East Journal of Scientific Research. 2012;11(9):12201225.

4. Islam $M$, Saha $S$, Akand $H$, Rahim A. Effect of sowing date on the growth and yield of sweet pepper (Capsicum annuum L.). Agronomski Glasnik. 2010;72(1):3-14.

5. Todorova V, Todorov $\mathrm{Y}$, Cholakov $\mathrm{T}$. Association between cultivar performance for economic and morphologic traits and agrometeorological factors in Bulgarian pepper (Capsicum annuum L.). Revista UDO Agrícola. 2009;9(4):776-81.

6. Gvozdenović Đ. Pepper. Institute of field and vegetable crops. Novi Sad: Tampograf; 2010.

7. Jankuloski D. Study of biological, morphological and qualitative traits of important populations of long peppers in Macedonia. PhD thesis. Skopje: Faculty of Agriculture; 1983.

8. Rahman MJ, Inden $\mathrm{H}$. Effect of nutrient solution and temperature on capsaicin content and yield contributing characteristics in six sweet pepper (Capsicum annuum L.) cultivars. J Food Agri Environ. 2012;10(1):524-529.

9. International Plant Genetic Resources Institute. Descriptors for Capsicum (Capsicum spp.). Rome, Italy; the Asian Vegetable Research and Development Center, Taipei, and the Centro Agronómico Tropical de Investigación y Enseñanza, Turrialba, Costa Rica; 1995.

10. Trajkova F. Characterization and agronomic evaluation of some pepper lines (Capsicum annuum L.) obtained via androgenesis. Doctoral dissertation. Faculty of Agriculture, Ss. Cyril and Methodius University, Skopje; 2013.

11. Irikova T, Grozeva S, Rodeva V. Anther culture in pepper (Capsicum annuum L.) in vitro. Acta Physiolgiae Plant. 2011;33: 1559-1570.

12. Luitel BP, Adhikari PB, Shrestha SL, Kang $\mathrm{WH}$. Morphological characterization of anther derived plants in minipaprika (Capsicum annuum L.). Korean Journal of Breeding Science. 2012;44(4):450-61.

13. Todorova V, Grozeva S, Rodeva V, Masheva S. Breeding evaluation of pepper lines obtained by in vitro anther culture. Genetika. 2013;45(2):601-10.

14. Nowaczyk L, Nowaczyk P, Olszewska D. Genetic analysis of anther culture-derived diploids of Capsicum spp. The Journal of Horticultural Science and Biotechnology. 2015;90(6):747-752.

15. Olszewska D, Niklas-Nowak A, Nowaczyk $P$. Variation in the quantitative characters of androgenic pepper lines derived from hybrid Capsicum frutescens L. x C. chinense JACQ. Vegetable Crops Research Bulletin. 2010;73(1):5-11.

16. Dumas de Valux $R$, Chambonnet $D$, Pochard E. In vitro culture of pepper (Capsicum annuum L.) Anthers: High rate plant production from different genotypes by $+35^{\circ} \mathrm{C}$ treatments. Agronomie. 1981; 1(10):859-864.

17. Koleva Gudeva L, Trajkova F, Dimeska G, Spasenoski M. Androgenesis efficiency in anther culture of pepper (C. annuum L.). Acta Hort. (ISHS). 2009;830:183-190.

18. Koleva Gudeva L, Trajkova F. Application of androgenesis as method for improvement of agricultural crops diversity. III Congress of ecologists of Macedonia with international participation. Book of proceedings. 2008;284-290.

19. Koleva Gudeva L, Trajkova F. Seed production from pepper obtained in in vitro anther culture. Yearbook of Institute of Southern Crops - Strumica 2004/2005. 2004;IV(V):85-93.

20. Ministry of Agriculture, Forestry and Water management of Republic of Macedonia. Directorate of Seed and Seedling Material. National variety list of Republic of Macedonia. Skopje; 2008.

21. Russo VM. Peppers: Botany, production and uses. Croydon: CABI; 2012.

22. Aleemullah $M$, Haigh $A M$, Holford $P$. Anthesis, anther dehiscence, pistil 
receptivity and fruit development in the Longum group of Capsicum annuum. Aust J Exp Agr. 2000;40(5):755-62.

23. Rexford, A. Evaluation of genetic variability in agro-morphological and fruit quality traits of some hot pepper (Capsicum Sp.) genotypes. Doctoral dissertation, University of Ghana; 2015.

24. Shankarnag B, Madalageri MB, Mulge R. Manifestation of Heterosis for earliness, growth and early green fruit yield in chilli. Indian J. Hort. 2006;63:410-414.

25. Nagaraju MM, Sreelathakumary I, Celine VA, Devi CS, Manju P. Heterosis studies for growth, earliness, fruit yield and yield components in chilli (Capsicum annuum L.). Int. J. Curr. Microbiol. App. Sci, 2017; 6(6):1330-1336.

26. Sharma VK, Semwal CS, Uniyal SP. Genetic variability and character association analysis in bell pepper (Capsicum annuum L.). Journal of Horticulture and Forestry. 2010;2(3):58-65.

27. Aladzajkov, L. Horticulture. Skopje; 1966.

28. Sood S, Sood R, Sagar V, Sharma KC. Genetic variation and association analysis for fruit yield, agronomic and quality characters in bell pepper. International Journal of Vegetable Science. 2009;15(3): 272-284.

29. Rylski I. Pepper (Capsicum). In: Monselise $\mathrm{SP}$, editor. Handbook of fruit set and development. Boca Raton: CRC Press; 1986.

30. Geleta LF, Labuschagne MT. Estimates of combining ability for agronomic traits in pepper (Capsicum annuum L.). South African Journal of Plant and Soil. 2006; 23(2):73-77.

31. Shaked R, Rosenfeld K, Pressman E. The effect of low night temperatures on carbohydrates metabolism in developing pollen grains of pepper in relation to their number and functioning. Scientia Horticulturae. 2004;102(1):29-36.

32. Delelegn S, Belew D, Mohammed A, Getachew Y. Evaluation of elite hot pepper varieties (Capsicum spp.) for growth, dry pod yield and quality under Jimma Condition, South West Ethiopia. International Journal of Agricultural Research. 2014;9:364-374.

33. DeWitt D, Bosland PW. The complete chile pepper. Portland: Timber Press; 2009.

34. Cankaya S, Balkaya A, Karaagac O. Canonical correlation analysis for the determination of relationships between plant characters and yield components in red pepper [Capsicum annuum L. var. conoides (Mill.) Irish] genotypes. Spanish Journal of Agricultural Research. 2010; 8(1):67-73.

(c) 2017 Trajkova and Gudeva; This is an Open Access article distributed under the terms of the Creative Commons Attribution License (http://creativecommons.org/licenses/by/4.0), which permits unrestricted use, distribution, and reproduction in any medium, provided the original work is properly cited.

Peer-review history:

The peer review history for this paper can be accessed here: http://sciencedomain.org/review-history/21732 